\title{
PERAN EKONOMI KREATIF (SUBSEKTOR KULINER, KRIYA, DAN FESYEN) SERTA VARIABEL LAINNYA TERHADAP PENGANGGURAN
}

\author{
THE ROLE OF CREATIVE ECONOMY (CULINARY ARTS, CRAFTS, AND FASHION \\ SUBSECTOR) AND OTHER VARIABLES TOWARDS UNEMPLOYMENT RATE
}

\author{
Oqxa Vyedo S.Z' ${ }^{1}$ Atik Maratis Suhartini² \\ Politeknik Statistika STIS ${ }^{1}$ \\ Politeknik Statistika STIS ${ }^{2}$ \\ Jl. Otto Iskandardinata 64C Jakarta Timur \\ E-mail: 116.9348@stis.ac.id, 2atik@stis.ac.id
}

\begin{abstract}
ABSTRAK
Fenomena bonus demografi akan dihadapi Indonesia pada tahun 2030-2040. Pada periode tersebut jumlah penduduk usia produktif diprediksi akan mencapai 64 persen dari jumlah penduduk total. Hal ini menjadi salah satu tantangan tersendiri baik bagi pemerintah maupun masyarakat. Jika pemerintah gagal memanfaatkan fenomena terebut, maka akan terjadi peningkatan angka pengangguran. Saat ini pengangguran yang terjadi di Indonesia lebih didominasi pengangguran usia muda. Penduduk usia muda adalah penduduk yang kaya akan ilmu pengetahuan, inovasi, kreativitas, dan semangat pantang menyerah. Salah satu sektor yang dapat menampung ide-ide kreatif dan munculnya pengangguran muda ialah sektor ekonomi kreatif. Penelitian ini bertujuan untuk mengetahui peran sektor ekonomi kreatif dan variabelvariabel lain dalam mengatasi masalah pengangguran di Indonesia tahun 2016 dengan menggunakan metode analisis Principal Component Regression (PCR). Metode ini merupakan regresi linier berganda yang digabungkan dengan Principal Component Analysis (PCA). Hasil penelitian menunjukkan bahwa sektor ekonomi kreatif belum mampu menunjukkan pengaruh signifikan terhadap tingkat pengangguran pada tahun 2016. Sedangkan upah minimum provinsi, indeks pembangunan manusia, dan investasi berpengaruh positif terhadap tingkat pengangguran. Kontrol 3 arah antara pemerintah, pengusaha dan pekerja terhadap UMP, peningkatan skill kewirausahaan cari penganggur terdidik serta kebijakan pemerintah untuk investasi bisa diarahkan sebagian ke sector ekonomi kreatif sebagai alternative dalam mengatasi permasalahan perngangguran khususnya usia muda. Selain itu diperlukan data penelitian yang lebih panjang untuk mengetahui pengaruh sector ekonomi kreatif terhadap pengangguran.
\end{abstract}

Kata Kunci: pengangguran, ekonomi kreatif, regresi komponen utama (PCR)

Demographic bonus phenomenon will be faced by Indonesia in 2030-2040. During this period, the productive age population will reach 64 percent of the total population. It will become a challenge for both government and people. If government fails to take advantages of it, there will an increase in unemployment rate. Unemployment in Indonesia is dominated by youth currently. Young people are rich in science, innovation, creativity, and unyielding spirit. One sectos that accommodate the creative ideas and youth unemployment problem is creative sector. The study aims to analyze role of creative sector and other variables in overcoming the unemployment problem in Indonesia 2016 by Principal Component Regression (PCR) analysis. It is a multiple linear regression combined with Principal Component Analysis (PCA). The results shows that creative sector is not showing significant effect yet on unemployment rate in 2016. Meanwhile, provincial minimum wage, human development index, and investment have positive effect on unemployment rate. Control of three directions between government, entrepreneur and workers on UMP stipulation, increasing in entrepreneurial skills for educated unemployed specially the youth and government policies for investment that can be directed partially to the creative sector, all as an alternative in overcoming unemployment problems, especially the youth. In addition, longer research data is needed to determine the effect of creative sector on unemployment.

Keywords: unemployment rate, creative economy, principal component regression (PCR) 


\section{PENDAHULUAN}

\section{Latar Belakang}

Fenomena bonus demografi akan dihadapi Indonesia pada tahun 2030-2040 dimana jumlah penduduk usia produktif akan mencapai 64 persen dari jumlah penduduk total (Bappenas, 2017). Hal tersebut tentu saja menjadi salah satu tantangan tersendiri baik bagi pemerintah maupun masyarakat. Melimpahnya penduduk usia produktif pada era ini akan membawa dampak positif jika dapat dimanfaatkan secara optimal. Sebaliknya akan memberikan dampak negatif jika gagal dalam memanfaatkannya sehingga dapat berdampak pada meningkatnya pengangguran dan beban ekonomi. Terlebih Indonesia dihadapkan pada era digital atau revolusi industri 4.0 dimana mesin dan manusia mulai terhubung dengan internet of things. Pada era ini efisiensi yang tinggi akan terjadi pada setiap tahapan proses industri. Namun revolusi industri 4.0 menuntut adanya keahlian dan kreativitas dimana hal tersebut merupakan ancaman bagi penduduk usia produktif yang tidak memilikinya yang berujung pada pengangguran. Pemerintah sebagai pegambil kebijakan tentunya sudah mengantisipasi hal ini melalui kebijakan yang sudah dilaksanakan maupun direncanakan, supaya penduduk usia produktif tersebut memiliki keahlian dan keterampilan sehingga tidak terjerumus menjadi pengangguran.

Dewasa ini pengangguran di Indonesia didominasi di usia muda yaitu usia 15 - 24 tahun (www.bps.go.id). Tahun 2013 saja, angka Tingkat Pengangguran Terbuka (TPT) usia muda tujuh kali lebih tinggi dari angka TPT usia dewasa (Putra, 2018). Penduduk usia muda ialah penduduk yang memiliki potensi besar akan ilmu pengetahuan, inovasi, kreativitas, dan semangat pantang menyerah diharapkan mampu membantu pemerintah dalam mengatasi masalah pengangguran. Namun, pada Februari 2019 jumlah pengangguran terbesar di Indonesia berada pada kelompok umur 20-24 tahun dan persentase jumlah pengangguran terhadap jumlah angkatan kerja terbesar berada pada kelompok umur 15-19 tahun. Hal ini menunjukkan bahwa sebenarnya pengangguran di Indonesia didominasi oleh kelompok usia muda. Salah satu sektor yang mampu menampung ide-ide inovatif dan kreatif dari generasi muda ialah sektor ekonomi kreatif (ekraf). Ekonomi kreatif memanfaatkan daya cipta dan kreasi individu sebagai basis utama dalam proses produksi. Hal itu tentu saja dapat menjadi salah satu solusi dalam mengatasi permasalahan pengangguran.

Ekonomi kreatif merupakan sektor yang mengedepankan konsep padat karya (Purnomo, 2016), artinya sektor ini mengedepankan faktor produksi yang berasal dari tenaga kerja manusia. Seharusnya tidaklah sulit bagi sektor ini untuk menyerap lebih banyak tenaga kerja khususnya tenaga kerja muda sehingga mampu menekan angka pengangguran. Terlebih sektor ekonomi kreatif sebagian besar didominasi oleh unit Usaha Mikro dan Kecil (UMK) yang tentunya memiliki kemampuan dalam menyerap tenaga kerja dengan skala yang besar. Dalam beberapa tahun terakhir, ekraf merupakan salah satu sektor yang mampu memberi kontribusi besar bagi perekonomian Indonesia baik dari sisi pendapatan maupun jumlah tenaga kerja. Pada 2016 PDB ekraf mencapai angka Rp. 922,59 triliun yang mampu menyumbang sebesar 7,44 persen terhadap PDB Nasional. Terdapat tiga subsektor penyumbang paling besar terhadap PDB ekraf yaitu kuliner, fesyen, dan kriya dengan total kontribusi sebesar 74,81 persen. Dilihat dari sisi ekspor, ekspor ekraf mencapai US\$ 20 Miliar atau 13,77 persen ekspor nasional dengan 99,86 persen dari angka tersebut berasal dari subsektor fesyen, kriya, dan kuliner. Penyerapan tenaga kerja pada tahun 2016 relatif tinggi yakni 16,91 juta tenaga kerja atau sebesar 14,28 persen terhadap tenaga kerja nasional dengan kontribusi terbesar berasal dari subsektor kuliner, fesyen, dan kriya yaitu sebesar 93,62 persen.

Cukup besarnya peran yang diberikan oleh sektor ekraf pada perekonomian Indonesia, seharusnya mampu mengatasi masalah pengangguran. Melihat besarnya jumlah tenaga kerja yang mampu terserap oleh sektor ekonomi kreatif, nyatanya belum mampu menekan angka pengangguran di Indonesia. Hal ini menjadi masalah penting yang harus segera dibenahi dari sektor ekraf sehingga mampu berkontribusi dalam menurunkan angka pengangguran di Indonesia.

Berdasarkan uraian latar belakang tersebut, penelitian ini bertujuan untuk menganalisis pengaruh sektor ekraf dan variabel lain pada masalah pengangguran di Indonesia. Dengan 
mengetahui pengaruh dari sektor ekraf diharapkan baik pemerintah maupun pelaku ekraf dapat saling bersinergi dalam mengatasi masalah pengangguran.

\section{Landasan Teori}

Pengangguran adalah suatu keadaan dimana seseorang yang tergolong dalam angkatan kerja ingin mendapatkan pekerjaan namun belum dapat memperolehnya (Sukirno, 2004:13). Untuk mengukur pengangguran, salah satu indikator yang dapat digunakan adalah Tingkat Pengangguran Terbuka (TPT). Menurut BPS, TPT ialah persentase jumlah pengangguran terhadap angkatan kerja.

Menurut Diktum Pertama Intstruksi Presiden No. 6 Tahun 2009 yang dimaksud ekonomi kreatif adalah kegiatan ekonomi berdasarkan kreativitas, keterampilan, dan bakat individu untuk menciptakan daya kreasi dan daya cipta individu yang bernilai ekonomis dan berpengaruh pada kesejahteraan masyarakat. Sektor ekonomi kreatif memiliki 16 subsektor dengan 3 subsektor unggulan yang berkontribusi besar terhadap PDB, ekspor, dan penyerapan tenaga kerja ekraf yakni subsektor kuliner, fesyen, dan kriya.

Usaha ekonomi kreatif adalah entitas usaha baik yang berbadan hukum maupun tidak berbadan hukum yang mentransformasikan dan memanfaatkan kreativitas untuk menghasilkan barang dan jasa serta yang diakui memiliki hak kekayaan intelektual baik terdaftar maupun melekat (Bekraf, 2018). Jumlah unit usaha menggambarkan lapangan pekerjaan yang tersedia. Maka pertumbuhan unit usaha pada suatu daerah atau sektor akan menambah jumlah lapangan pekerjaan yang menambah permintaan terhadap tenaga kerja sehingga penyerapan tenaga kerja semakin besar.

Upah minimum ialah upah bulanan terendah yang terdiri atas upah pokok termasuk tunjangan tetap yang ditetapkan oleh gubernur. Kemudian Upah Minimum Provinsi (UMP) adalah upah yang berlaku untuk seluruh kabupaten/kota di suatu provinsi. Mankiw (2009) mengatakan salah satu faktor munculnya pengangguran ialah kekakuan upah yang berarti kegagalan upah dalam melakukan penyesuaian ke suatu level dimana penawaran tenaga kerja sama dengan permintaannya.

Indeks Pembangunan Manusia (IPM) merupakan suatu indeks yang digunakan untuk mengukur capaian pembangunan manusia di suatu wilayah yang dibangun melalui tiga dimensi dasar yakni dimensi umur panjang dan hidup sehat; pengetahuan; dan standar hidup layak (BPS, 2019). Semakin baik tingkat kesehatan, pendidikan, dan kehidupan tenaga kerja akan menghasilkan pekerjaan yang berkualitas sehingga akan meningkatkan permintaan tenaga kerja (Mahroji dan Nurkhasanah, 2019). Peningkatan daya beli masyarakat menunjukkan peningkatan pada permintaan agregat. Apabila permintaan agregat rendah maka perusahaan akan menurunkan jumlah produksi dan tidak mampu menyerap tenaga kerja.

Investasi merupakan sebuah pengeluaran atau pembelanjaan penanam-penanam suatu modal atau perusahaan untuk membeli barang-barang modal dan perlengkapan produksi untuk menambah kemampuan memproduksi barang-barang dan jasa-jasa yang tersedia dalam perekonomian (Sukirno, 2004). Investasi merupakan suatu input suatu kegiatan ekonomi yang nantinya akan mempengaruhi jumlah penyerapan tenaga kerja (Yanti dkk, 2019). Semakin tinggi investasi maka akan semakin besar kapasitas produksi suatu perusahaan sehingga membutuhkan faktor produksi (tenaga kerja) yang besar. Karena tenaga kerja yang terserap semakin besar maka tingkat pengangguran akan menurun.

\section{METODE}

Penelitian ini menggunakan metode analisis Principal Component Regression (PCR) yang menggabungkan metode regresi linier berganda dengan Principal Component Analysis (PCA). Penggunaan PCA sebagai analisis lanjutan dari regresi linier berganda dikarenakan terjadinya pelanggaran salah satu asumsi klasik untuk menghasilkan estimator yang terbaik, linier, dan tidak bias yakni asumsi non multikolinieritas (Jolliffe, 2002). Sedangkan komponen utama tidak 
berkorelasi maka tidak akan ada multikolinieritas dan perhitungan regresi juga menjadi lebih sederhana serta menghasilkan persamaan yang lebih stabil (Flury dan Riedwyl, 1988:212). Prosedur yang dilakukan dalam penelitian ini adalah sebagai berikut:

1. Mendefinisikan variabel dependen $Y$ yaitu tingkat pengangguran terbuka dan variabel independent $X$ yakni jumlah unit usaha subsektor kuliner, jumlah unit usaha subsektor kriya, jumlah unit usaha subsektor fesyen, UMP, IPM, dan investasi.

2. Melakukan analisis RLB untuk mendapatkan model regresi menggunakan metode estimasi OLS.

TPT $_{i}=\beta_{0}+\beta_{1}$ Kuliner $_{i}+\beta_{2}$ Kriya $_{i}+\beta_{3}$ Fesyen $_{i}+\beta_{4} U M P_{i}+\beta_{5}$ IPM $_{i}+\beta_{6}$ Investasi $_{i}+\varepsilon_{i}$

Keterangan:

$\mathrm{TPT}_{\mathrm{i}} \quad$ : Tingkat pengangguran terbuka di provinsi ke-i (persen)

Kuliner $_{i} \quad$ : Jumlah unit usaha subsektor kuliner di provinsi ke-i (ribu unit)

Kriya $_{\text {: }} \quad$ : Jumlah unit usaha subsektor kriya di provinsi ke-i (ribu unit)

Fesyen $_{\mathrm{i}} \quad$ : Jumlah unit usaha subsektor fesyen di provinsi ke-i (ribu unit)

$\mathrm{UMP}_{\mathrm{i}} \quad$ : Upah minimum di provinsi ke-i (juta rupiah)

IPM $_{\mathrm{i}} \quad$ : IPM di provinsi ke-i

Investasi $i_{i} \quad$ : Investasi di provinsi ke-i (triliun rupiah)

$\varepsilon_{\mathrm{i}} \quad:$ Komponen error model

i $\quad$ : Provinsi di Indonesia sebanyak 34 provinsi

3. Menguji asumsi klasik yakni normalitas, homoskedastisitas, dan non multikolinieritas.

4. Mangatasi pelanggaran asumsi non multikolinieritas menggunakan metode PCA.

5. Meregresikan variabel dependen dengan skor komponen utama terpilih.

6. Menguji pelanggaran asumsi non multikolinieritas.

7. Menguji signifikansi parameter secara parsial.

8. Mentransformasikan variabel hasil standardisasi (Z) kembali ke variabel asal (X).

\section{HASIL DAN PEMBAHASAN}

\section{Mendefinisikan Variabel Dependen dan Independen}

Pada penelitian ini variabel dependen yang digunakan ialah tingkat pengangguran terbuka dan variabel independen yang digunakan yakni jumlah unit usaha subsektor kuliner, jumlah unit usaha subsektor kriya, jumlah unit usaha subsektor fesyen, UMP, IPM, dan investasi.

\section{Hasil Regresi Linier Berganda}

Untuk melihat hubungan antara tingkat pengangguran terbuka dengan jumlah unit usaha subsektor kuliner, jumlah unit usaha subsektor kriya, UMP, IPM, dan investasi digunakan analisis regresi linier berganda dengan metode estimasi Ordinary Least Squares (OLS). Hasil dari estimasi tersebut dapat dilihat pada lampiran 1 yang menghasilkan persamaan regresi sebagai berikut:

$\widehat{T P T}=-12,9907+0,0177$ Kuliner $^{*}-0,0696$ Kriya $-0,0268$ Fesyen $+2,9446$ UMP $^{*}+$ 0,1824 IPM* - 0,0071 Investasi ${ }^{*}$

Ket: $*$ ) signifikan pada $a=5$ persen

Dari hasil estimasi tersebut dapat dilihat bahwa model pada persamaan 2 memiliki $R$-squared $=$ 0,4496 . Artinya variasi tingkat pengangguran terbuka yang mampu dijelaskan oleh variabel independent di dalam model sebesar 44,96 persen sedangkan sisanya dijelaskan oleh variabel lain yang tidak masuk di dalam model. Selanjutnya hasil pada uji $F$ menunjukkan $p$-value sebesar $0,0085<a=0,05$ artinya terdapat minimal satu variabel independen yang berpengaruh signifikan terhadap tingkat pengangguran terbuka. Selain itu, jika variabel independen diuji secara parsial menunjukkan bahwa jumlah unit usaha subsector kuliner, UMP, IPM, dan investasi memiliki perngaruh yang signifikan terhadap tingkat pengangguran terbuka pada tingkat signifikansi 5 
persen sedangkan jumlah unit subsektor kriya dan fesyen belum terbukti signifikan mempengaruhi tingkat pengangguran.

\section{Pengujian Asumsi Klasik}

Setelah melakukan regresi linier berganda, selanjutnya dilakukan pengujian asumsi klasik regresi yakni normalitas, homoskedastisitas, dan non multikolinieritas. Pengujian asumsi normalitas menggunakan uji Jarque-Bera untuk menguji apakah residual pada model berditribusi normal atau tidak. Kemudian pengujian asumsi homoskedastisitas menggunakan uji Breusch-Pagan-Godfrey untuk menguji apakah residual pada model memiliki varians yang konstan atau tidak. Sementara pengujian asumsi non multikolinieritas menggunakan nilai VIF untuk menguji apakah terdapat hubungan linier antar variabel independent atau tidak.

Berdasarkan lampiran 2, uji Jarque-Bera memberikan hasil $p$-value $=0,2365>0,05$ sehingga keputusan yang diambil ialah gagal tolak $\mathrm{H}_{0}$ yang berarti residual pada model sudah berdistribusi normal. Selanjutnya berdasarkan lampiran 3, uji Breusch-Pagan-Godfrey memberikan hasil $p$-value $=0,8119>\mathrm{a}=0,05$ sehingga keputusan yang diambil ialah gagal tolak $\mathrm{H}_{0}$ yang berarti residual memiliki varinas yang konstan. Sedangkan pengujian asumsi non-multikolinieritas pada lampiran 4, menunjukkan adanya variabel independent yang memiliki nilai VIF lebih dari 10 yang berarti terjadi pelanggaran asumsi non multikolinieritas sehingga diatasi dengan menggunakan Principal Component Analysis (PCA).

\section{Penanganan Pelanggaran Asumsi Non Multikolinieritas Menggunakan PCA}

a. Melakukan standardisasi variabel independent dengan scale dan centering.

b. Dengan melakukan PCA diperoleh nilai eigen dan vector eigen pada lampiran 5.

c. Berdasarkan lampiran 5, terlihat bahwa PC1 dan PC2 memiliki nilai eigen lebih dari 1. yang mampu menjelaskan 83,73 persen variasi dari seluruh variabel independent sehingga komponen yang akan digunakan untuk analisis lanjutan ialah PC1 dan PC2.

d. Berdasarkan lampiran 5, didapatkan persamaan komponen terpilih yakni PC1 dan PC2 sebagai berikut:

$$
\begin{aligned}
& P C 1=0,516 Z_{\text {kuliner }}+0,504 Z_{\text {kriya }}+0,517 Z_{\text {fesyen }}-0,105 Z_{U M P}+0,176 Z_{I P M}+0,413 Z_{\text {investasi }}(3) \\
& P C 2=0,115 Z_{\text {kuliner }}+0,208 Z_{\text {kriya }}-0,696 Z_{U M P}-0,518 Z_{I P M}-0,433 Z_{\text {investasi }} \ldots \ldots \ldots \ldots \ldots \ldots \ldots \ldots . . .(4)
\end{aligned}
$$

e. Dengan menggunakan persamaan 3 dan 4 diperoleh skor komponen utama

\section{Regresi Komponen Utama}

Berdasarkan hasil PCA digunakan 2 komponen utama yakni PC1 dan PC2 yang mampu menjelaskan 83,73 persen variasi, maka kedua komponen tersebut sudah laik digunakan sebagai variabel baru yang saling bebas untuk analisis regresi lanjutan. Kemudian menggunakan estimasi OLS diperoleh hasil persamaan regresi komponen utama pada lampiran 6 yang menghasilkan persamaan regresi komponen utama:

$$
\widehat{T P T}=5,0187+0,1237 P C 1-0,6723 P C 2
$$

\section{Pengujian Asumsi Non Multikolinieritas}

Dari hasil regresi komponen utama pada langkah sebelumnya, kemudian dilakukan pengujian asumsi non multikolinieritas. Lampiran 7 menunjukkan bahwa nilai VIF PC1 dan PC2 kurang dari 10 yang menandakan bahwa tidak terjadi pelanggaran asumsi non multikolinieritas.

\section{Pengujian Signifikansi Koefisien Regresi Komponen Utama}

Selanjutnya model yang telah didapat ditransformasikan kembali ke variabel Z sehingga diperoleh persamaan regresi dalam variabel baku sebagai berikut:

$$
\begin{aligned}
& \widehat{T P T}=5,0187-0,01349 Z_{\text {kuliner }}-0,07749 Z_{\text {kriya }}+0,06395 Z_{\text {fesyen }}+0,45493 Z_{U M P}+ \\
& 0,37002 Z_{I P M}+0,34219 Z_{\text {investasi }}
\end{aligned}
$$


Untuk melihat ada atau tidaknya pengaruh dari masing-masing variabel terhadap TPT dilakukan uji signifikansi koefisien regresi komponen utama yang terdapat pada tabel 1.

Tabel 1. Hasil Pengujian Signifikansi Koefisien Regresi Komponen Utama

\begin{tabular}{|l|l|l|l|l|}
\hline Variabel & Koefisien & Varians & Simpangan Baku & t-hitung \\
\hline$Z_{\text {kuliner }}$ & $-0,01349$ & 0,003332 & 0,05772 & $-0,2337$ \\
\hline$Z_{\text {kriya }}$ & $-0,07749$ & 0,004242 & 0,06513 & $-1,1897$ \\
\hline$Z_{\text {fesyen }}$ & 0,06395 & 0,002237 & 0,04729 & 1,3523 \\
\hline$Z_{\text {UMP }}$ & 0,54932 & 0,005369 & 0,07327 & $6,2087^{*}$ \\
\hline$Z_{\text {IPM }}$ & 0,37002 & 0,000979 & 0,03128 & $11,9615^{*}$ \\
\hline$Z_{\text {investasi }}$ & 0,34219 & 0,000003 & 0,00183 & $187,0377^{*}$ \\
\hline
\end{tabular}

Ket: * signifikan pada $\mathrm{a}=5$ persen

Dengan menggunakan $\mathrm{t}_{(0,05 ; 28)}=2,048$ maka variabel yang signifikan mempengaruhi tingkat pengangguran terbuka pada tingkat signifikansi 5 persen ialah UMP, IPM, dan investasi. Model akhir yang diperoleh terdapat pada persamaan 7.

\section{Tranformasi Variabel Baku (Z) ke Variabel Awal (X)}

Agar dapat diinterpretasikan dengan mudah maka variabel baku (Z) ditranformasikan kembali ke variabel asal $(X)$. Tranformasi ini menggunakan perhitungan matematis berdasarkan beberapa persamaan yang diperoleh sebelumnya.

$\widehat{T P T}=-3,56247-0,000047$ Kuliner $-0,00258$ Kriya + 0,04035 Fesyen $+1,13703$ UMP $P^{*}+$ 0,08915 IPM $^{*}+0,00199$ Investasi $^{*}$

Ket: $*$ signifikan pada $a=5$ persen

\section{Hubungan Subsektor Kuliner, Kriya, dan Fesyen dengan Tingkat Pengangguran Terbuka}

Berdasarkan hasil regresi pada persamaan 7, sektor ekonomi kreatif belum mampu menunjukkan pengaruh signifikan terhadap tingkat pengangguran. Pada dasarnya peningkatan jumlah unit usaha di ketiga subsektor ekonomi kreatif tersebut, tidak serta merta di periode yang sama akan menurunkan pengangguran. Ketika sebuah usaha berdiri khususnya Mikro dan Kecil (UMK), usaha ini biasanya menggunakan modal sendiri dengan kemampuan pendanaan tidak seluas ketika usaha tersebut mendapat suntikan dana dari perbankan. Dampaknya tenaga kerja yang digunakan tidak terlalu banyak bahkan dijalankan sendiri dan atau dengan tenaga kerja tidak dibayar (pekerja keluarga). Sehingga memerlukan beberapa waktu hingga usaha ini mampu menyerap tenaga kerja dan mengurangi pengangguran. Sehingga penggunaan data 1 tahun dirasa belum mampu menunjukkan pengaruh jumlah unit usaha dari ketiga subsektor ekonomi kreatif ini dalam menurunkan pengangguran. Akan tetapi jika dilihat arah hubungannya, variabel jumlah unit usaha subsektor kuliner dan kriya berpengaruh negatif namun tidak signifikan terhadap TPT pada tingkat signifikansi 5 persen. Arah negatif ini mengindikasikan bahwa besarnya perluasan lapangan kerja melalui unit usaha subsektor kriya dan subsektor kuliner akan diikuti dengan penurunan tingkat pengangguran melalui penyerapan tenaga kerjanya. Sebaliknya subsektor fesyen memiliki arah hubungan yang positif dengan tingkat pengangguran. Hal ini terjadi karena peningkatan impor tekstil dan produk tekstil sehingga menciptakan persaingan pada produk-produk fesyen lokal (BPS, 2015). Hal tersebut dapat menyebabkan terjadinya penurunan produksi dari perusahaan lokal untuk menghindari adanya kerugian.

\section{Hubungan Upah Minimum Provinsi dengan Tingkat Pengangguran Terbuka}

Berdasarkan hasil regresi pada persamaan 7, Upah Minimum Provinsi (UMP) memiliki pengaruh yang positif dan signifikan terhadap Tingkat Pengangguran Terbuka (TPT) pada tingkat signifikansi 5 persen. Artinya semakin tinggi pemerintah provinsi menetapkan upah minimum, maka akan meningkatkan tingkat pengangguran. Nilai koefisien regresi variabel UMP sebesar 
1,13703 berarti setiap kenaikan satu juta rupiah pada upah yang ditetapkan suatu provinsi akan meningkatkan tingkat pengangguran secara rata-rata sebesar 1,13703 persen dengan asumsi variabel lain bersifat konstan.

Hubungan positif antara UMP dengan TPT dikarenakan terjadinya kekakuan upah (wage rigidity) yang berarti kegagalan upah dalam melakukan penyesuaian ke suatu level dimana penawaran tenaga kerja sama dengan permintaannya. Meningkatnya tingkat upah mengakibatkan penawaran tenaga kerja bertambah sedangkan permintaan tenaga kerja berkurang. Hal itu mengakibatkan terjadinya surplus tenaga kerja atau pengangguran (Mankiw, 2009). Selain itu ketika provinsi menetapkan upah minimum yang tinggi maka perusahaan akan meningkatkan harga barang yang diproduksi agar tetap mendapat keuntungan. Namun konsumen akan merespon dengan mengurangi konsumsi barang tersebut sehingga perusahaan terpaksa menurunkan jumlah produksinya yang juga akan mengurangi tenaga kerja yang dibutuhkan. Penelitian yang dilakukan oleh Panjawa dan Soebagiyo (2014) menunjukkan bahwa upah minimum memiliki pengaruh positif dan signifikan terhadap tingkat pengaangguran di Karesidenan Surakarta.

Kondisi ini memerlukan kerjasama ketiga pihak yaitu pemerintah, pengusaha dan pekerja supaya UMP yang ditetapkan tidak merugikan pengusaha akan tetapi juga tidak merugikan tenaga kerja. Kerjasama yang baik antara ketiga pihak tersebut, tentunya tidak akan memberikan beban berlebihan bagi pengusaha untuk mengembangkan usahanya dan membuka lapangan pekerjaan baru tanpa ada yang dirugikan dan pada akhirnya akan mengurangi pengangguran.

\section{Hubungan Indeks Pembangunan Manusia dengan Tingkat Pengangguran Terbuka}

Berdasarkan hasil regresi pada persamaan 7, Indeks Pembangunan Manusia (IPM) memiliki pengaruh yang positif dan signifikan terhadap Tingkat Pengangguran Terbuka (TPT) pada tingkat signifikansi 5 persen. Hal ini memiliki arti jika IPM suatu provinsi meningkat maka akan meningkatkan tingkat pengangguran di provinsi bersangkutan. Nilai koefisien regresi variabel IPM sebesar 0,08915 berarti setiap kenaikan IPM suatu provinsi sebesar satu satuan maka secara ratarata tingkat pengangguran provinsi terkait akan meningkat sebesar 0,08915 persen dengan asumsi variabel lain bersifat konstan.

Hubungan antara IPM dengan TPT menunjukkan hal yang berbeda dengan landasan teori yang menyatakan bahwa IPM berpengaruh negative terhadap tingkat pengangguran. Faktor yang menyebabkan naiknya tingkat pengangguran ketika IPM meningkat salah satunya karena adanya tingkat pengangguran terdidik. Menurut BPS, pada tahun 2016 sebesar 57,61 persen dari pengangguran yang ada ialah pengangguran tamatan SMA dan perguruan tinggi. Besarnya tingkat pengangguran terdidik ini tentunya akan menaikkan nilai IPM yang diraih oleh suatu provinsi. Selain itu jika dilihat dari tingkat pendidikan angkatan kerja yang bekerja, sebesar 60,75 persen tenaga kerja tersebut ialah tamatan SMP ke bawah. Jika dilihat dari sisi penawaran tenaga kerja, semakin tinggi IPM di suatu daerah maka tenaga kerja tersebut tentunya akan menaikkan reservation wage. Ehrenberg (dalam Astusi, 2013) menyatakan bahwa semakin tinggi pendidikan maka reservation wage orang tersebut juga semakin tinggi sehingga ia akan memilih mejadi penganggur sampai ia menemukan pekerjaan yang sesuai dengan reservation wage yang ia tetapkan. Penelitian yang dilakukan oleh M. Arizal dan Marwan (2019) juga menunjukkan hal yang serupa bahwa IPM berpengaruh positif dan signifikan terhadap TPT.

Pemerintah sebagai pengambil kebijakan bisa meningkatkan sosialisasi tentang pelatihan pelatihan gratis yang sudah dilakukannya melalui Depnaker, sehingga penganggur khususnya yang terdidik bisa memperoleh skill baru atau mendalami skill yang telah dimiliki untuk membuka lapangan pekerjaan sendiri. Setidaknya penganggur bisa membuka lapangan pekerjaan untuk diri sendiri dan atau memiliki skill lebih untuk baik untuk meningkatkan peluang dalam mencaari pekerjaan. Sehingga pada akhirnya akan mengurangi pengangguran.

\section{Hubungan Investasi dengan Tingkat Pengangguran Terbuka}

Berdasarkan hasil regresi pada persamaan 7, investasi memiliki pengaruh yang positif dan signifikan terhadap Tingkat Pengangguran Terbuka (TPT). Artinya jika investasi di suatu provinsi meningkat maka tingkat pengangguran di provinsi bersangkutan juga meningkat. Nilai koefisien 
regresi variabel sebesar 0,00199 yang berarti setiap kenaikan investasi di suatu provinsi sebesar satu trilliun rupiah maka secara rata-rata tingkat pengangguran di provinsi terkait akan meningkat sebesar 0,00199 persen dengan asumsi variabel lain bersifat konstan.

Hubungan antara investasi dengan TPT menunjukkan hal yang berbeda dengan landasan teori yang menyatakan bahwa investasi berpengaruh negative terhadap tingkat pengangguran. Faktor yang menyebabkan naiknya tingkat pengangguran ketika nilai investasi meningkat ialah terus menurunnya penyerapan tenaga kerja karena investasi. Menurut BKPM, Rp. 1 triliun investasi menyerap 3089 pekerja dan terus menurun hingga pada tahun 2016 hanya menyerap 2272 pekerja. Menurunnya penyerapan tenaga kerja ini disebabkan oleh investasi yang banyak bergerak di sektor padat modal sebagai konsekuensi dari era revolusi industri 4.0 dimana teknologi mengambil alih peran manusia. Hal ini sejalan dengan penelitian Said (2017) berjudul pengaruh upah minimum regional, investasi, pertumbuhan ekonomi terhadap pengangguran di Kota Makassar yang menyatakan bahwa investasi mempengaruhi tingkat pengangguran secara positif.

Pemerintah sebagai pegambil kebijakan bisa mengatur dan menentukan arah investasi ke sector yang padat karya, seperti sektor ekraf. Investasi tersebut tentunya akan membuka lapangan pekerjaan baru dengan menyerap lebih banyak tenaga kerja dan mengurangi pengangguran.

\section{KESIMPULAN}

Sektor ekonomi kreatif khususnya subsektor kuliner, kriya, dan fesyen belum dapat menunjukkan pengaruh yang signifikan terhadap tingkat pengangguran dalam jangka waktu satu tahun. Sehingga diperlukan periode data penelitian yang lebih lama untuk mengetahui dampaknya. Sedangkan UMP, IPM, dan investasi berpengaruh signifikan. Jika dilihat arah hubungannya jumlah unit usaha subsektor kuliner dan kriya berhubungan negatif yang berarti peningkatan jumlah unit usaha subsector kuliner dan kriya akan menyerap tenaga kerja baru yang bisa mengurangi pengangguran. Sedangkan jumlah unit usaha subsektor fesyen berhubungan positif terhadap tingkat pengangguran terbuka salah satunya karena banyaknya impor feshen murah dari China. Demikian juga dengan UMP, IPM, dan investasi yang memiliki pengaurh positif signifikan terhadap pengangguran.

Kerjasama antara pemerintah, pengusaha dan pekerja dalam penentuan UMP, peningkatan sosialisasi terhadap pelatihan gratis yang diadakan pemerintah khususnya bagi penganggur terdidik, serta kebijakan pemerintah dalam mengalokasikan investasi di sector padat karya seperti ekraf akan mampu mengurangi pengangguran. Serta penambahan data penelitian perlu dilakukan untuk mengetahui dampak dari sector ekraf terhadap pengangguran.

\section{UCAPAN TERIMA KASIH}

Penulis mengucapkan terima kasih yang sebesar-besarnya kehadirat Allah SWT atas ijin dan ridhoNya, orang tua dengan segenap doa dan dukungan penuh, dosen pembimbing dan semua rekan yang terlibat baik langsung maupun tidak, Badan Pusat Statistik, Badan Ekonomi Kreatif, dan lingkungan Politeknik Statistika STIS keseluruhan atas kesempatan dan kemudahan dalam keseluruhan proses penelitian.

\section{DAFTAR PUSTAKA}

Arizal, M. dan Marwan. (2019). Pengaruh Produk Domestik Regional Bruto dan Indeks Pembangunan Manusia Terhadap Tingkat Pengangguran Terbuka di Provinsi Sumatera Barat. Jurnal Ecogen. 2(3): 433-442

Astuti, Maidiana. (2013). Faktor-Faktor yang Mempengaruhi Lama Menganggur Bagi Pekerja di Industri Perkebunan Kelapa Sawit Ogan Komering Ulu. Jurnal IImiah STIE MDP 2(2): 130-149

Badan Ekonomi Kreatif. (2018). OPUS Ekonomi Kreatif Outlook 2019. Jakarta: BEKRAF

Badan Ekonomi Kreatif. (2018). Rencana Strategis Badan Ekonomi Kreatif 2015-2019. Jakarta: BEKRAF 
Badan Ekonomi Kreatif. (2019). Infografis Sebaran Pelaku Ekonomi Kreatf. Jakarta: BEKRAF

Badan Pusat Statistik. (2016). Produk Domestik Bruto Indonesia Menurut Pengeluaran 2011-2015. Jakarta: BPS

Badan Pusat Statistik. 2020. Tabel Tingkat Pengangguran Terbuka menurut Umur. Disadur tanggal 19 Agustus 2020 dari web BPS www.bps.go.id

Bappenas. (2017). Bonus Demografi 2030-2040: Strategi Indonesia Terkait Ketenagakerjaan dan Pendidikan. Siaran Pers. $22 \mathrm{Mei}$

Flury, B. dan Riedwyl, H. (1988). Multivariate Statistics: A Practical Approach. London: Chapman \& Hall, Ltd.

Gujarati, Damodar. (2004). Basic Econometrics, Fourth Edition. Singapore: The McGraw-Hill Companies.

Hajrah, H. (2017). Pengaruh Nilai Produksi, Investasi, dan Jumlah Unit Usaha Terhadap Penyerapan Tenaga Kerja Pada Sektor Industri Kecil dan Menengah di Kota Makassar. [Skripsi]. Makassar: Universitas Islam Negeri Alauddin Makassar.

Johnson, R.A., dan Wichern, D. W. (2007). Applied Multivariate Statistical Analysis. New Jersey: Pearson Education, Inc.

Jollife IT. (2002). Principal Component Analysis Second Edition. New York: Springer-Verlag

Mankiw, N. Gregory. (2009). Macroeconomics 7th Edition. New York: Worth Publishers

Panjawa, J. Lukis dan Soebagiyo, D. (2014). Efek Peningkatan Upah Minimum Terhadap Tingkat Pengangguran. Jurnal Ekonomi \& Studi Pembangunan 15(1): 48-54

Purnomo, Rochmat Aldy. (2016). Ekonomi Kreatif Pilar Pembangunan Indonesia. Artikel: Nulisbuku.com

Putra, Maulana Eka dan Iskandar, Deden Dinar (2018). Determinan Status Pengangguran Usia Muda Perkotaan dan Perdesaan di Indonesia. Jurnal Ilmu Ekonomi Terapan Vol 3 (2) : $44-70$ ISSN 25411470. Universitas Dipenogoro Semarang

Sukirno, Sadono. (2004). Makro Ekonomi Teori Pengantar. Jakarta: PT Raja Grafindo Persada

Said, Nurhikmah R. (2017). Pengaruh Upah Minimum Regional, Investasi, dan Pertumbuhan Ekonomi Terhadap Pengangguran di Kota Makassar. [Skripsi]. Makassar: Universitas Islam Negeri Alauddin Makassar

Yanti, Nur Fitri dkk, (2017). Analisis Pengaruh Inflasi, Investasi, dan PDRB Terhadap Tingkat Pengangguran di Wilayah Sulawesi Periode 2010-2014. E Jurnal Katalogis 5(4): 138-149.

\section{LAMPIRAN}

\section{Lampiran 1. Output Regresi Linier Berganda}

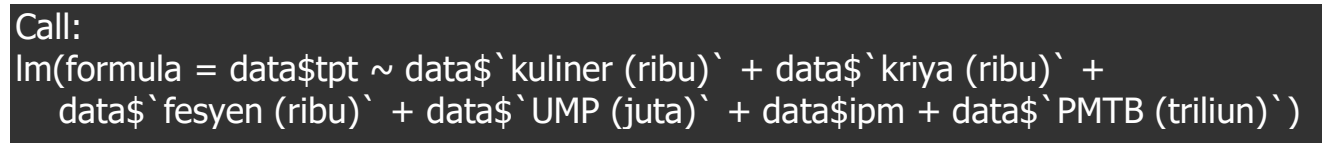




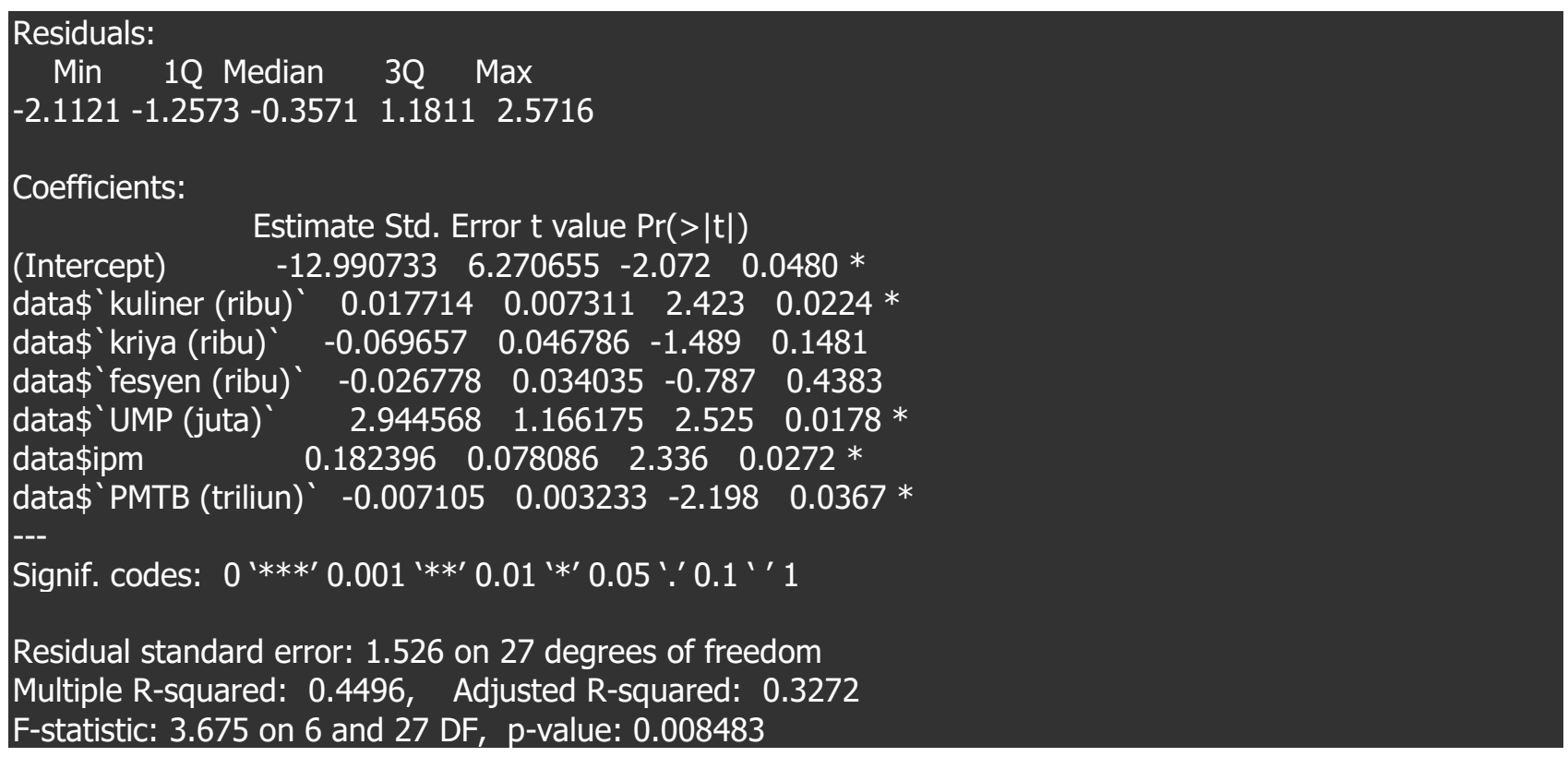

\title{
Lampiran 2. Output Hasil Uji Jarque-Bera
}

\author{
Jarque Bera Test
}

data: residual 11

X-squared $=2.8839, \mathrm{df}=2, \mathrm{p}$-value $=0.2365$

\section{Lampiran 3. Output Hasil Uji Breusch-Pagan-Godfrey}

Breusch-Pagan test

data: reg

$\mathrm{BP}=2.9757, \mathrm{df}=6, \mathrm{p}$-value $=0.8119$

\section{Lampiran 4. Output Nilai VIF}

\begin{tabular}{|c|c|}
\hline $\begin{array}{r}\text { data\$ kuliner (ribu) } \\
63.243229 \\
\text { data\$ UMP (juta) }\end{array}$ & $\begin{array}{cc}\text { data\$ kriya (ribu)` data\$` fesyen (ribu) } \\
27.975583 & 71.937463 \\
\text { data\$ipm data\$ }{ }^{\prime} \text { PMTB (triliun) }\end{array}$ \\
\hline 3.087092 & 4.385059 \\
\hline
\end{tabular}

\section{Lampiran 5. Nilai eigen dan Vektor eigen}

Importance of components:

$$
\text { Comp.1 Comp. } 2 \text { Comp. } 3 \text { Comp.4 Comp. } 5 \quad \text { Comp. } 6
$$

Standard deviation $\quad \begin{aligned} & 1.8684433 \\ & 1.1766941\end{aligned} 0.8665140 \quad 0.40605106 \quad 0.1558486240 .088472493$

Proportion of Variance 0.59947840 .23776120 .12893320 .028312290 .0041708030 .001344096

Cumulative Proportion 0.59947840 .83723960 .96617280 .994485100 .9986559041 .000000000 


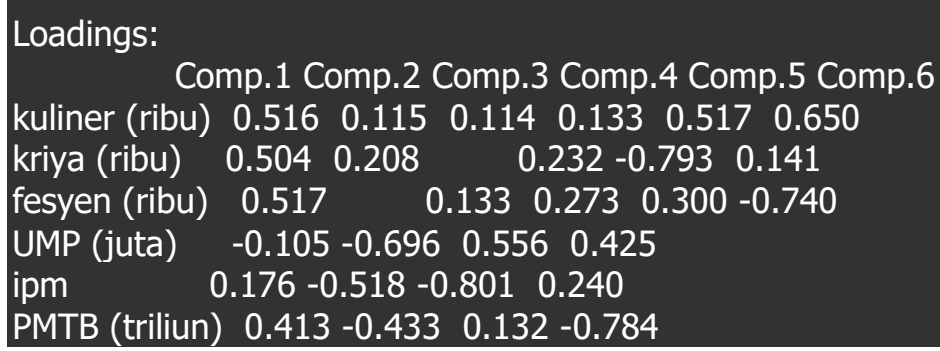

\section{Lampiran 6. Output Hasil Regresi Komponen Utama}

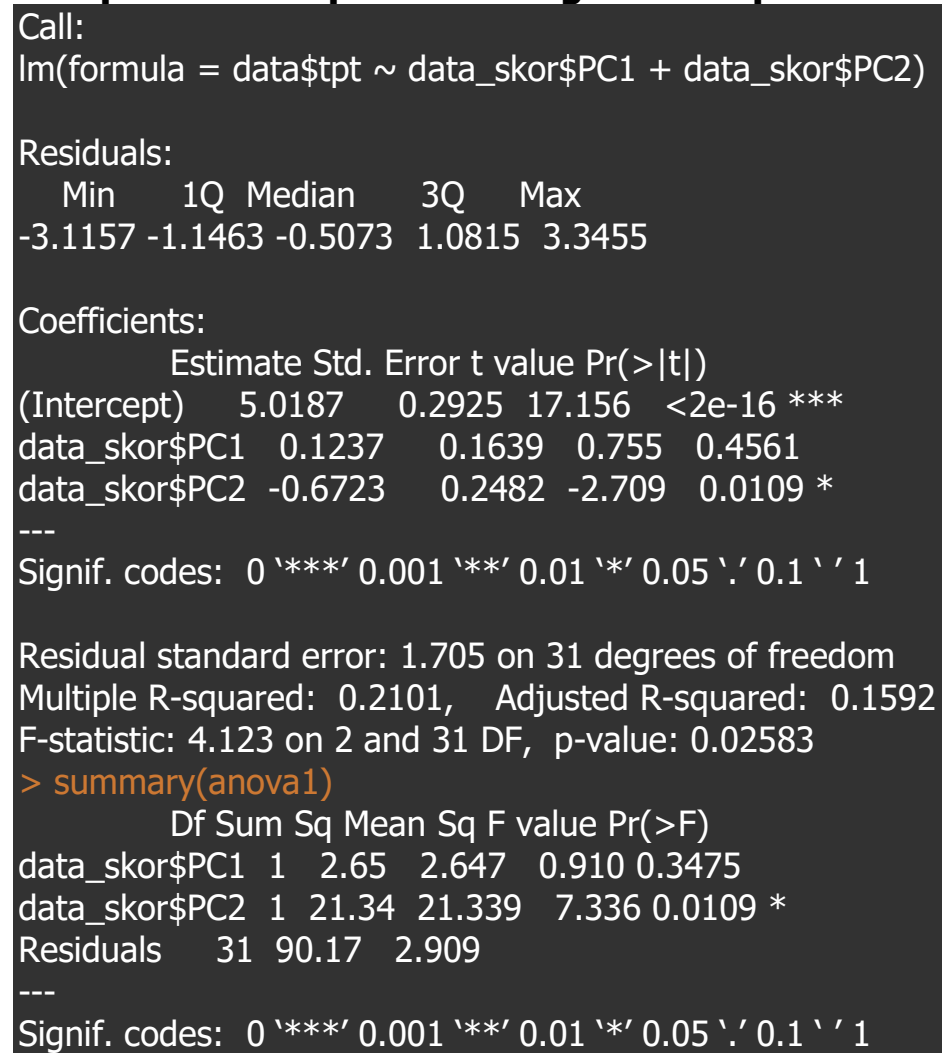

\section{Lampiran 7. Output Nilai VIF Regresi Komponen Utama}

data skor\$PC1 data skor\$PC2

$$
1.005298 \quad 1.005298
$$

